\title{
THE MEASUREMENT OF THE CIRCULATING RED CELL VOLUME BY MEANS OF TWO RADIOACTIVE ISOTOPES OF IRON ${ }^{1}$
}

\author{
By JOHN G. GIBSON, 2ND, SOMA WEISS, 2 ROBLEY D. EVANS, WENDELL C. \\ PEACOCK, JOHN W. IRVINE, JR., WILFRED M. GOOD, \\ AND ARTHUR F. KIP \\ (From the Radioactivity Center, Massachusetts Institute of Technology, Cambridge; the \\ Medical Clinic of the Peter Bent Brigham Hospital, and Department \\ of Medicine, Harvard Medical School, Boston)
}

(Received for publication January 18, 1946)

Measurement of blood volume, both of its plasma and red cell portion, is a useful tool in clinical and experimental investigation. It provides basic data for the assay of the total quantity of individual blood components, as well as for the evaluation of observed hemodynamic changes in acute or chronic disturbances of the circulation. Blood volume determinations have proved of value in the study of congestive heart failure, the anemias, thyroid disorders, renal disease, and pregnancy; and they have been particularly useful during the recent war years in the study of hemorrhage, burns and shock, and in the development of blood substitutes and blood cell preservatives.

It seems reasonable to state that the dye method $(1,2)$ measures the circulating plasma volume with a high degree of accuracy both in normal and pathologic states, and in many clinical and experimentally induced abnormal circulatory conditions. This view appears to be shared by investigators who have had firsthand experience with the technique $(3,4)$.

Perhaps the best experimental evidence that the method accurately measures changes in plasma volume was obtained in a series of experiments in which the increase in plasma volume following the intravenous injection of concentrated ( 25 per cent) human serum albumin was measured (5). The osmotic equivalent of 1 gram of this protein was found by Scatchard et al (6) to be $18 \mathrm{ml}$. of $\mathrm{H}_{2} \mathrm{O}$; the average increase in plasma volume in 11 male human subjects was $17.4 \mathrm{ml}$. of $\mathrm{H}_{2} \mathrm{O}$ (5) per gram of albumin.

1 The work described in this paper was done under a contract, recommended by the Committee on Medical Research, between the Office of Scientific Research and Development and the Massachusetts Institute of Technology, in collaboration with the Peter Bent Brigham Hospital.

2 Deceased, January 31, 1942.
Total blood volume and red cell volume can be calculated from the plasma volume and the venous, auricular or arterial hematocrit. This indirect measurement is based on the assumption that the ratio of cells to plasma is a constant throughout the entire vascular tree. It has long been suspected that this is not true.

Smith et al (7) found that the red cell volume as determined by the Welcker method (exsanguination) and the carbon monoxide method was consistently lower than when calculated from the hematocrit and plasma volume measured by the dye method of Keith, Rowntree and Geraghty (8). Since the first 2 methods were independent of the hematocrit, they concluded that the cell to plasma ratio was different in large and small vessels.

Fåhraeus in 1929 (9) reported experiments in which normal blood was allowed to stream through glass capillary tubes ranging from 1.1 to $0.050 \mathrm{~mm}$. in diameter. The ratio of cells to plasma remained fairly constant, averaging about 40 per cent, until the diameter of the tube was less than $0.1 \mathrm{~mm}$., but as the diameter was further decreased, the proportion of erythrocytes fell rapidly, being only 28 per cent in tubes of $0.050 \mathrm{~mm}$. ( 50 microns). This size of tube is comparable to the larger capillaries. An even lower hematocrit might be expected to occur in blood flowing through smaller capillaries.

The problem was studied by Stead and associates in normal humans (10) and in splenectomized dogs (11) in 1940-41. Plasma and red cell volumes were determined by the dye method prior to a single large hemorrhage. These observations were repeated at intervals during the next 4 to 6 days. The expected cell volume at the time of repeated volume determinations was calculated by subtracting the quantity of red cells removed 
by hemorrhage, and by subsequent sampling from the original cell volume. As the hematocrit of the venous blood fell due to hemodilution the observed cell volume became progressively less than the expected cell volume, even though the observations were made during a period when some regeneration of red cells may have been taking place. If, to the lowest observed cell volume the total quantity of red cells removed was added, the sum was always less than the observed pre-hemorrhage volume.

These studies supported the view that the red cell volume, as measured by the dye-plasma-hematocrit technique, was always higher than the true red cell volume.

The use of a diffusible gas, $\mathrm{CO}$, having a high affinity for human hemoglobin, was suggested as a means of tagging red cells by Chang and Harrop (12). Following inhalation of $\mathrm{CO}$, a certain proportion would be absorbed into and remain within the red cells for a considerable period. The quantity of gas absorbed by the individual cell would then vary with the partial pressure of $\mathrm{CO}$ in the pulmonary alveoli, but not with the ratio of cells to plasma in the blood stream. Hence the measurement, obtained from $\mathrm{CO}$ analysis of whole blood samples was, in theory, a measure of total circulating blood volume. The plasma volume could then be calculated from the large vessel hematocrit.

Hopper et al (13) recently reported on simultaneous measurements of blood volume in man and dog by means of Evans blue and CO. No consistent discrepancy in the results of the 2 methods was observed in normal subjects. The ratio of dye to $\mathrm{CO}$ determined total blood volume ranged from 0.91 to 1.16 in humans, and from 0.84 to 1.16 in normal and splenectomized dogs. The numerical average of these ratios was very close to unity. A more variable relationship was found in abnormal subjects. Dye volumes were considerably higher than $\mathrm{CO}$ volumes in dogs in experimental traumatic shock, the discrepancy tending to increase as the hematocrit rose with hemoconcentration (14).

Just as the dye plasma volume technique is based on controlled studies of the mechanism of the removal of dye from the blood stream, the $\mathrm{CO}$ method must be carried out with some regard to the fate of the gas in the body. At the present time this knowledge is far from complete.

In 1940, Hahn and Hevesy (15) labelled the phosphatides, and acid-soluble organic phosphorus compounds of rabbits with radioactive phosphorus $\left(\mathrm{P}^{32}\right)$. Some of these tagged compounds were incorporated in newly developing red cells, or entered them by interchange between circulating cells and plasma. These tagged cells were injected intravenously into other rabbits, and blood samples were taken at intervals thereafter. The phosphatides of both donor and recipient cells were extracted, and the contained phosphorus was precipitated and measured for radioactivity with a Geiger counter. Total blood volume was computed from the ratio of the radioactivity, expressed as units per ml. of whole blood, of donor and recipient samples. It was found that the recipient's red corpuscle content of $\mathrm{P}^{32}$ rapidly diminished after the injection of tagged cells, a fact which imposes several limitations on the use of the technique. The basic measurement was the radioactivity of the corpuscles; the assumption again being that the cell to plasma ratio was a constant throughout the vascular system.

All of these studies pointed to the desirability of a simple, accurate and dependable method of determining circulating red cell volume which could be used simultaneously with plasma volume determinations and other circulatory studies.

Hahn et al, in 1942, described a method of measuring red cell volume by means of a radioactive isotope of iron (16). They found that radioactive iron administered to dogs becomes incorporated in the hemoglobin of new erythrocytes, and that these cells do not release this radio-iron as long as they remain intact. When such tagged cells are given to another dog, the degree of dilution thereof in the non-radioactive cells, determined by radioactivity analyses of samples of recipient's cells, gives a measurement of total circulating red cell volume. This value is independent of variations of the cell-plasma ratio throughout the vascular tree. Since the recipient's cell radioactivity levels do not vary to any extent in from 1 to 3 days after the infusion of tagged cells, it is evident that all of the transfused cells are well retained and become completely mixed with all the cells in the circulation. 
These workers simultaneously determined the dye-plasma-hematocrit cell volume and radio-iron cell volume in 13 dogs. The cell volume calculated from the plasma volume was higher than the radio-iron cell volume in all cases, the ratio of the latter to the former value ranging from 0.61 to 0.92 , with an average of 0.71 . Their report constitutes the first study of circulating red cell volume by a reliable specific method. Their results confirm previously expressed theoretical and experimental reasons for ciriticism of the dyeplasma-hematocrit cell volume determination.

The methods described herein are elaborations of the original technique of these workers for the purpose of applying it to a wide variety of experimental and clinical studies in animals and humans.

The measurement of red cell volume by means of erythrocytes tagged with radioactive iron is based on two assumptions, (1) that none of the radioactive atoms of iron pass out through the membrane of the intact erythrocytes, and (2) that all of the transfused tagged cells become thoroughly mixed with all of the recipient's cells; i.e., the ratio of radioactive to non-radioactive cells becomes, and remains a constant throughout the entire vascular tree, and hence is independent of differences in hematocrit levels in large and small vessels.

The validity of the first assumption has been demonstrated by in vitro experiments. Radioiron dog cells were carefully washed in isotonic saline and added to whole heparinized blood from a dog which had never received radio-iron, and thoroughly mixed. The mixture was then centrifuged. No hemolysis occurred. There was no detectable radioactivity in aliquots of the supernatant plasma. Repeated washing of the cells with isotonic saline also failed to show any detectable radioactivity in the washings.

The validity of the second assumption has been established both indirectly by in vitro, and directly by in vivo experiments in dogs and humans. Compatible radioactive human erythrocytes were added to heparinized whole blood from a normal human. The experiment simulated the repeated determination of circulating cell volume before and after a hemorrhage in vivo. The data from a typical experiment, given in Table I, show that recovery was complete within \pm 3 per cent.

Unanesthetized animals, 1 normal and 1 splenec-
TABLE I

Recovery of radioactive cells added to non-radioactive whole human blood

\begin{tabular}{|c|c|c|c|}
\hline \multirow{2}{*}{ Procedure } & \multicolumn{2}{|c|}{ Unit activities* } & \multirow{2}{*}{$\begin{array}{l}\text { Per cent } t \\
\text { recovery }\end{array}$} \\
\hline & $\begin{array}{l}\text { Calcu- } \\
\text { lated }\end{array}$ & Found & \\
\hline $\begin{array}{l}\text { Radioactive cells added } \\
\text { Non-radioactive whole blood } \\
\text { added }\end{array}$ & $\begin{array}{l}0.647 \\
0.368\end{array}$ & $\begin{array}{l}0.672 \\
0.359\end{array}$ & $\begin{array}{r}103.5 \\
97.5\end{array}$ \\
\hline $\begin{array}{l}\text { Whole blood removed and radio- } \\
\text { active cells again added }\end{array}$ & 1.480 & 1.500 & 98.7 \\
\hline
\end{tabular}

* Unit activity $=\frac{\mathrm{cpm} \text { per ml. of cells. }}{\mathrm{cmp} \text { of standard } \mathrm{Fe}}$

tomized, were bled amounts insufficient to produce any appreciable fall in mean arterial pressure, and radio-iron cell volumes were determined before and after hemorrhage. The final cell volume plus the known quantity of cells withdrawn was equal to the prehemorrhage cell volume within \pm 3.0 per cent (Table II).

In similar experiments in 2 moderately anemic patients the increase in cell volume as measured by radio-iron before and after transfusions of fresh compatible blood was equal to the known

TABLE II

Measurement of total circulating red cell volume before and after hemorrhage in unanesthetized dogs

\begin{tabular}{|c|c|c|}
\hline & $\begin{array}{l}\text { Red cell } \\
\text { volume }\end{array}$ & Error \\
\hline \multicolumn{3}{|l|}{ Dog No. 4-Splenectomized } \\
\hline $\begin{array}{l}\text { Before bleeding } \\
\text { Loss of red cells (direct measurement) } \\
\text { Calculated volume after bleeding } \\
\text { Volume measured } 24 \text { hours after bleeding }\end{array}$ & $\begin{array}{c}m l . \\
527 \\
190 \\
382 \\
373\end{array}$ & -2.3 \\
\hline
\end{tabular}

Dog No. 6-Normal

\begin{tabular}{l|l|l}
\hline & $m l$. & \\
Before bleeding & 645 & \\
Loss of red cells (direct measurement) & 135 & \\
Calculated volume after bleeding & 510 & \\
Volume measured 3 days after bleeding & 520 & +2.0
\end{tabular}

Dog No. 7-Normal

Before bleeding

Loss of red cells (direct measurement)

Calculated volume after bleeding

Volume 6 days after bleedings

Infusion of Beef Albumin

Calculated volume after infusion

Volume measured after infusion

$-5.4$

230

$220-4.3$ 
amount of cells infused within \pm 2 per cent (Table III).

The fact that the addition or subtraction of known amounts of red cells to the circulation is accurately measured in these experiments indicates that the tagged red cells have become intimately

TABLE III

Measurement of total circulating red cell volume before and after transfusion in patients with anemia

\begin{tabular}{l|c}
\hline \hline Procedure & $\begin{array}{c}\text { Red } \\
\text { cell } \\
\text { volume }\end{array}$ \\
\hline
\end{tabular}

Patient 0.0. Aged 56. Anemia due to blood loss

\begin{tabular}{l|l|l}
\hline & $m l$. & per cent \\
Before transfusion & 515 & \\
Net cells given (direct measurement) & 400 & \\
Calculated volume after transfusion & 915 & \\
Measured volume 20 hours after transfusion & 905 & -1.1 \\
\hline
\end{tabular}

Patient C.D. Aged 23. Idiopathic hypochromic anemia

\begin{tabular}{l|r|r}
\hline & $m l$. & \\
Before transfusion & 820 & \\
Net cells given (direct measurement) & 800 & \\
Calculated volume after transfusion & 1620 & \\
Measured volume 21 hours after transfusion & 1590 & -1.9 \\
\hline
\end{tabular}

mixed with the other red cells in the blood vessels. Positive evidence that this is the case lies in the fact that the ratio of radioactive to total cells does not change after the removal of a quantity of whole blood (Figure 4).

\section{Preperation of radioactive red cell donors.}

Human donors whose cells were of blood group-O (socalled universal donors) have been used routinely in these studies, since their cells are not agglutinated by the serum of any of the 4 blood groups. We have selected $\mathrm{Rh}+$ donors, since the majority of humans are $\mathrm{Rh}+$. It is hardly necessary to point out the hazards of giving $\mathrm{Rh}+$ cells to $\mathrm{Rh}$ - recipients; but $\mathrm{Rh}$ - donors can be prepared. It is advisable that donor serum have low anti-A and anti-B titers.

The preparation of the two isotopes, $\mathrm{Fe}^{\mathrm{m}}$ and $\mathrm{Fe}^{\mathrm{ss}}$, and their synthesis into ferric ammonium citrate and preparation for intravenous use has been described in a previous communication (17). No effects attributable to radiation from either isotope have been observed following intravenous injection of neutral aqueous solutions of ferric ammonium citrate in the dosage used: $1 \mathrm{mgm}$. or less per injection (17).

The efficiency of utilization, in normal humans, of both isotopes of radio-iron, when given intravenously in small doses ( $1 \mathrm{mgm}$.), is striking. Radioactive cells are detectable in the blood stream within 24 hours after admin- istration, the maximum level being attained in about 21 days. Thereafter the cell radioactivity level fluctuates little, being affected chiefly by the decay of the isotopes, the withdrawal of red cells, and the natural excretion of body iron. Bleeding prior to radio-iron administration has been found to have little or no effect on utilization, even in individuals in normal iron balance, probably because the amounts given represent less than 1 per cent of total iron stores.

The utilization of radioactive iron following a single intravenous injection has been carefully observed in 3 normal males. The percentage of the administered radioiron utilized was calculated from the known quantity of radioactivity given, the subject's red cell volume (estimated from plasma volume and hematocrit corrected by a factor of 0.85 ), and the radioactivity of red cell samples taken daily. The maximum utilization was about 80 per cent.

The data obtained are shown in Figure 1, in which the uptake is shown as a percentage of the total utilization during the period of observation. It will be noted that the experimental data conform closely to an exponential curve beginning 24 hours after injection, having a half period value of approximately $3 \frac{11}{2}$ days. Since the radioactivity of blood samples derives only from new cells in active circulation, this curve is also an index of the rate of withdrawal of radio-iron from the body iron stores.

The quantity of radio-iron necessary to administer to a donor depends upon the specific radioactivity (counts per minute per mgm. of iron), of the individual lot of iron, and the radioactivity level per ml. of donor's cells required for the intended experiments. Each lot of ferric ammonium citrate varies in specific activity, and also, as finally prepared, in the concentration of the solution. It has been our practice to dilute each lot so that each 10 $\mathrm{ml}$. ampul contained approximately $1 \mathrm{mgm}$. of $\mathrm{Fe}^{+++}$, and this has been used as a standard dose. Specific activities of $\mathrm{Fe}^{\mathrm{s5}}$ have ranged from $1 \times 10^{6}$ to $6 \times 10^{6}$ c.p.m. per $\mathrm{mgm}$. Fe per ampul, and of $\mathrm{Fe}^{\mathrm{s}}$ from $1 \times 10^{\circ}$ to $2 \times 10^{7}$. Thus the preparation of donors can be accomplished in a short time with a few injections.

Since the requirements of each type of experiment vary, no hard and fast set of rules for all procedures can be laid down.

Based on observations of over 40 normal human donors, several of whom have received both isotopes, it seems safe to say that at least 60 per cent of the iron injected will be utilized whether given in single or multiple injections. Figure 2 is a nomogram showing the approximate radioactivity level of donors' red cells resulting from a total dosage of from $1 \times 10^{8}$ to $1 \times 10^{7}$ c.p.m., in normal individuals having red cell volumes ranging from $1000 \mathrm{ml}$. to $3000 \mathrm{ml}$. Variations in individual uptake will occur, but the nomogram has proved useful as a first approximation in the preparation of donors.

With present counters used by us, sufficiently accurate measurements can be made when a given red cell sample contains a total of about 250 c.p.m. above background. Since about $5 \mathrm{ml}$. of cells are taken for each sample, the 
radioactivity of the donor cells should be such that, after mixing, the recipient's blood contains about 50 c.p.m. per $\mathrm{ml}$. of cells. Assuming the cell volume of a large normal adult male is $2500 \mathrm{ml}$., then the transfused tagged cells should contain a total of 125,000 c.p.m. It has been found practical to infuse about $100 \mathrm{ml}$. of donor's whole blood, containing 40 to $50 \mathrm{ml}$. of red cells. It follows that an adequate donor level may range from 2500 to 3000 c.p.m. per $\mathrm{ml}$. of cells. The quantity of cells given is equal to about 2 per cent of the normal red cell volume, well within the limits of error of the technique. Thus the recipient's cell volume is not materially changed by the infusion.

Some degree of latitude obtains, but in general, the quantity of donor cells required for a single volume determination can be closely estimated. A nomogram for the purpose is given in Figure 3. This shows the minimum quantity of donor's cells, with radioactivity levels ranging from 500 to 5000 c.p.m. per $\mathrm{ml}$. that must be given to individuals having red cell volumes as high as $3000 \mathrm{ml}$. to obtain a level of at least 50 c.p.m. per ml. of recipient's cells.

A brief study of these nomograms indicates that for single volumes in normal adult humans, an infusion of from 70 to $100 \mathrm{ml}$. of whole donor blood (30 to $50 \mathrm{ml}$. of red cells) having an activity of about 2500 c.p.m. per ml. will give satisfactory recipient cell radioactivity levels in individuals having red cell volumes of from 1500 to $2500 \mathrm{ml}$.

These radiation levels are quite safe for donors and we have had donors with twice these levels who have shown no untoward effects. Higher levels are unnecessary for routine cell volume measurements. Donors have been used repeatedly over periods for as long as 3 years. Since the decay rate of $\mathrm{Fe}^{\mathrm{s}}$ is 10 per cent per week, occasional booster doses may be necessary and can be given without increasing radiation risks. No booster doses are needed when the 5 year isotope, $\mathrm{Fe}^{\mathrm{sb}}$, is used.

\section{The determination of red cell volume.}

The techniques described below have been developed in our laboratories for the measurement of cell volume in humans and dogs. The underlying principles are, however, applicable to a variety of experimental procedures each imposing a diversity of limiting factors. The techniques are identical for blood samples containing either one or both isotopes.

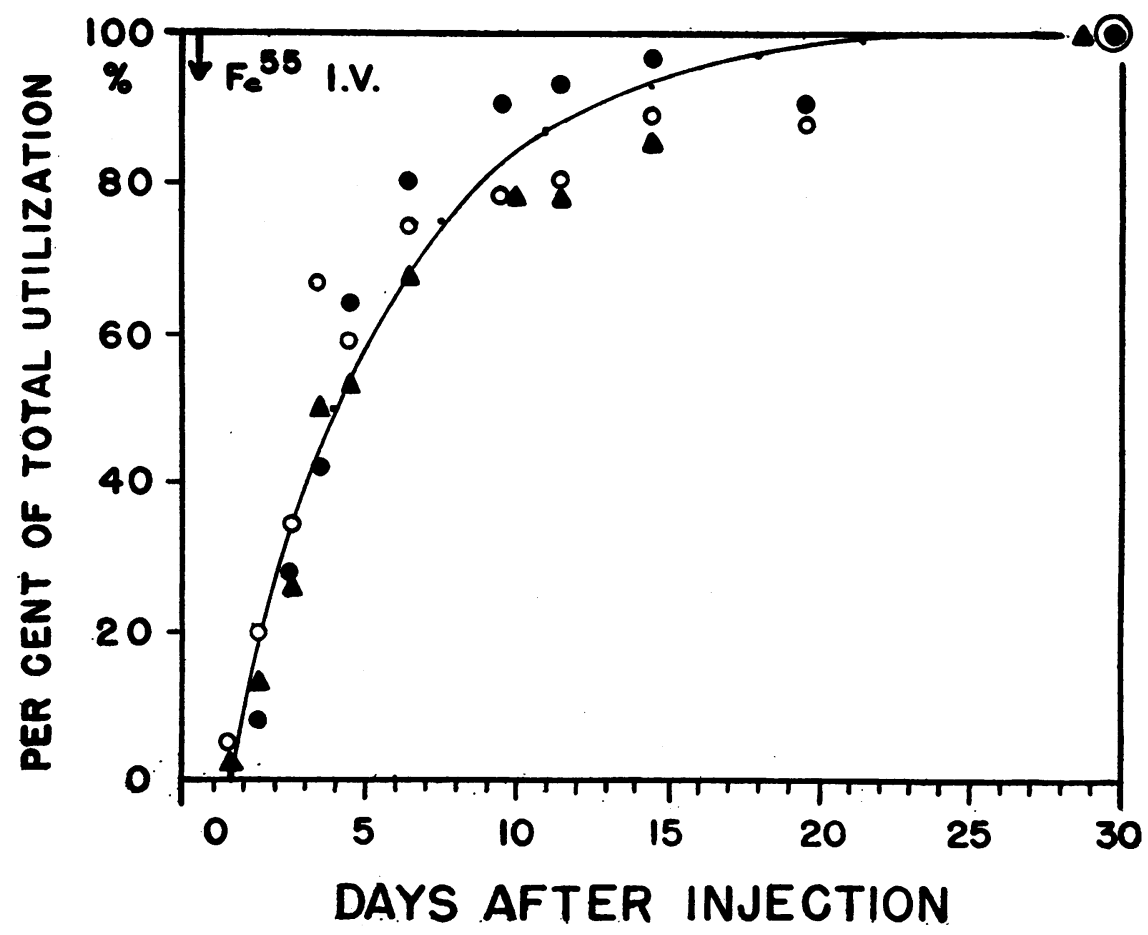

Fig. 1. Utilization of Intravenously Injected Radioactive Iron

The subjects were males in normal iron balance, and in all 3 approximately 80 per cent of the administered radio-iron was found in circulating red cells at the end of the observation period. The percentages of utilization plotted are normalized. The solid curve represents an exponential growth curve such that half of the radioactive iron available for red cell production is utilized every $3 \frac{1}{2}$ days. 


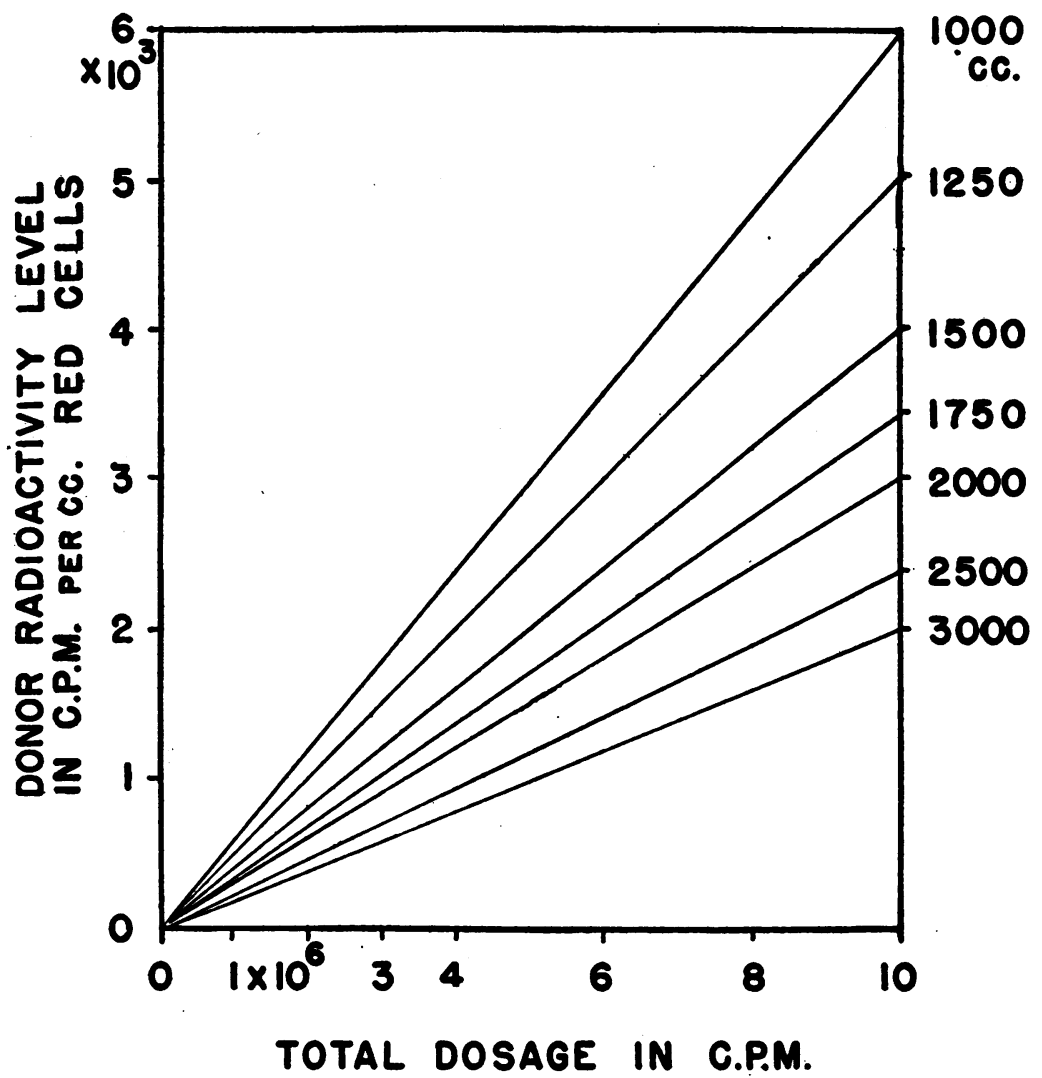

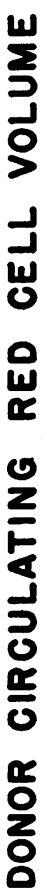

Fig. 2. Donor Red Cell Radioactivity Levels

Nomogram for approximation of donor red cell radioactivity in c.p.m. per $\mathrm{ml}$. of cells resulting from intravenous injection of radioactive ferric ammonium citrate in total dosage up to $1 \times 10^{7}$ c.p.m. (given either as a single or in multiple injections) in subjects whose total cell volume ranges from 1000 to $3000 \mathrm{ml}$.

\section{Preparation of donor's red cells for infusion.}

Red cells deteriorate rapidly at room temperature. It is essential that the donor blood be fresh if simple citrate solutions or heparin are used as anticoagulants. If the donor blood must be kept for more than 12 hours, it should be drawn into a preservative solution and kept at not over $10^{\circ} \mathrm{C}$. until shortly before it is used. The best preservative so far encountered is an acid-citrate-dextrose solution having the formula:

$$
\begin{aligned}
& \text { grams per } \\
& 100 \mathrm{ml} \text {. } \\
& \text { Tri-sodium citrate dihydride } \ldots \ldots \ldots \ldots \ldots 1.33 \\
& \text { Citric acid: } \mathrm{H}_{2} \mathrm{O} \ldots \ldots \ldots \ldots \ldots \ldots \ldots \ldots . .47 \\
& \text { Dextrose, anhydrous ................ } 3.00 \\
& \mathrm{pH} \ldots \ldots \ldots \ldots \ldots \ldots \ldots \ldots \ldots \ldots, 5.0
\end{aligned}
$$

The components are dissolved together in pyrogen-free distilled $\mathrm{H}_{2} \mathrm{O}$ and can be autoclaved without discoloration. Twenty-five $\mathrm{ml}$. of this solution are used for taking 100 ml. of whole blood. It is advisable to chill the solution before taking blood into it. Small fibrin clots may form, requiring filtration. The $\mathrm{pH}$ of the solution is 5.0 , and though not isotonic, it does not hemolyze cells or cause appreciable changes in cell dimensions because of the rapid buffering action of plasma protein and hemoglobin. Cells in this solution can be used for 5 days, since 90 to 95 per cent of them survive post-transfusion after 10 days of refrigerated storage. If fresh blood is used, filtering is unnecessary. The amount of blood given must be accurately measured, and syringes or delivery burettes should be calibrated to within $1 \mathrm{ml}$.

The sample of donor blood for radioactivity analysis is taken at the time of infusion. If the blood is filtered, the sample is of the filtered blood. All donor blood is thoroughly mixed by gentle rotation just prior to administration.

The donor blood is injected into the blood stream via vein, artery or auricle. After allowing 10 to 20 minutes for complete mixing to take place, a blood sample is taken, usually followed by 2 others at 10 to 15 minute intervals. Samples are taken without stasis. We have routinely taken $15 \mathrm{ml}$. of blood in round-bottomed graduated centrifuge tubes using heparin in the sampling syringe as an anticoagulant. If a dye-plasma volume is determined 
simultaneously, the sampling time schedule can be so arranged that plasma from the radio-iron samples may be used for dye colorimetry.

If the subject has never received radio-iron, it is unnecessary to take a blood sample before infusing the donor's blood. Should a second injection of radioactive cells be given for the repeated determination of cell volume, it is necessary to take a blood sample just prior to the second infusion. This sample is essential if non-radioactive red cells are given between measurements.

Recipient blood samples should never be taken through needles or syringes, etc., with which donor's blood has come in contact since large and uncorrectable errors may result from radioactive contamination.

Successive cell volume determinations can be carried out. Each volume is calculated from the net increase in radioactivity level resulting from the last injection of cells.

\section{Preparation of red cell samples for radioactivity measure- ment.}

The electroplating of iron in preparation for counting has been described elsewhere (17). Only the procedures involved in wet-ashing the blood samples and precipitating the iron will be described here.

\section{Blood donor samples.}

In order that counting rates on both donor and recipient samples have approximately the same probable error, it is desirable that both donor and recipient sample be in the same range of counting rate. Donor cell levels are always higher than recipient levels, usually by a factor of from 40 to 50 . The typical procedure is to dilute $2 \mathrm{ml}$. of whole donor's blood (using an Ostwald pipette) to $100 \mathrm{ml}$. in a volumetric flask and prepare 10 $\mathrm{ml}$. aliquots of this for analysis in duplicate. Wintrobe hematocrits, preferably in duplicate, are determined for each donor whole blood sample, and the number of $\mathrm{ml}$. of cells in the sample calculated from these values. Since recipient samples contain about $5 \mathrm{ml}$. of cells, donor and recipient radioactivity levels are approximately equal.

\section{Blood recipient samples.}

The $15 \mathrm{ml}$. graduated collecting tubes are centrifuged at 3000 r.p.m. for 30 minutes to obtain fairly complete packing. The number of $\mathrm{ml}$. of cells is noted to the nearest $0.1 \mathrm{ml}$. The hematocrit of the blood sample may also be noted. The plasma is then removed.

Once the donor blood has been diluted, or the plasma removed from the recipient cells, the samples can be

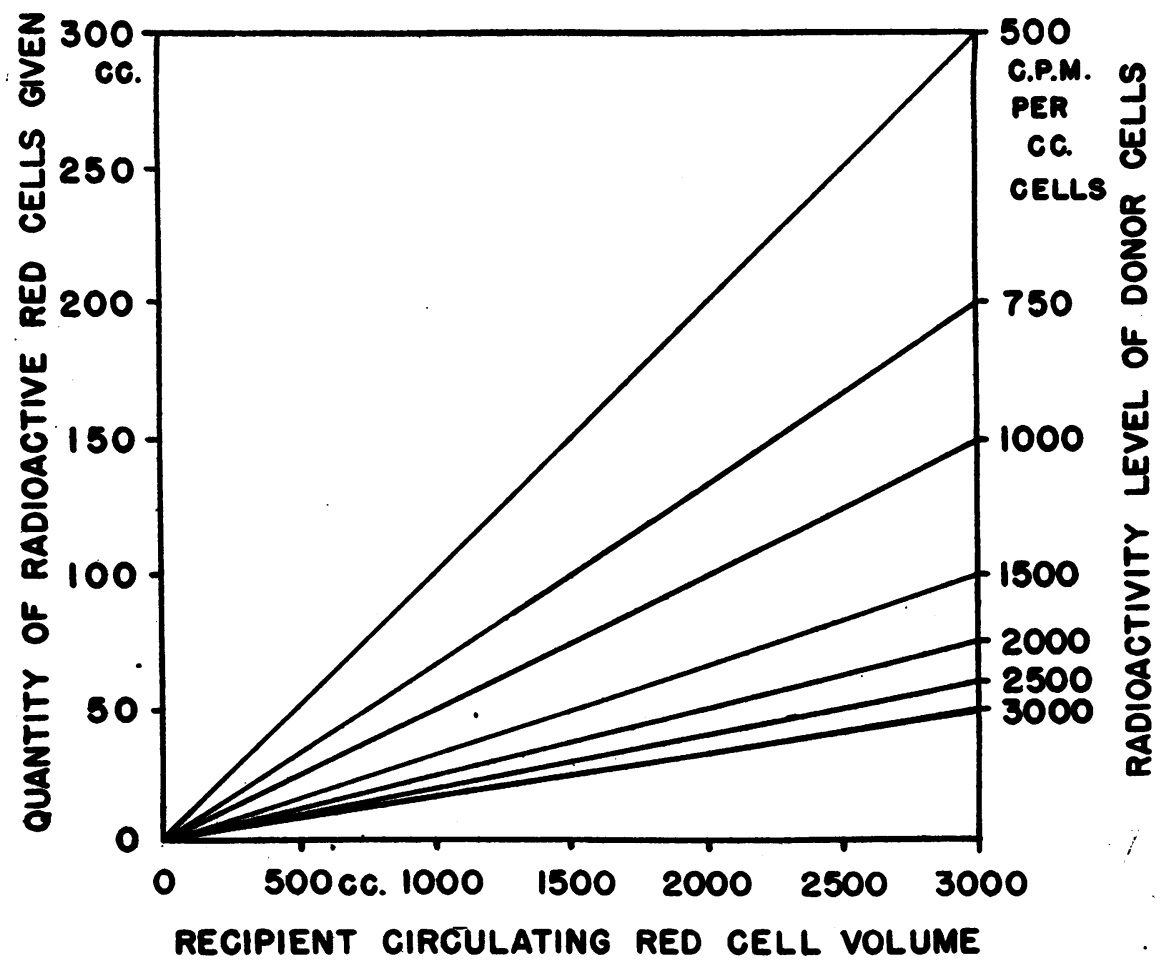

Fig. 3. Recipient Radioactivity Red Cell Levels

Nomogram for computation of the minimum quantity of donor red cells, the radioactivity of which is from 500 to 5000 c.p.m. per ml. necessary to obtain a minimum recipient red cell activity of 50 c.p.m. per $\mathrm{ml}$., in recipients whose total cell volume is between 500 and $3000 \mathrm{ml}$. 
stored for considerable periods of time before wet-ashing. This permits of transporting or shipping samples either as laked or packed cells. Wet-ashing and precipitation of iron has been described in a previous communication (17).

The protocol of a typical human experiment, ${ }^{3}$ in which

$\dot{s}$ This experiment was performed at Bellevue Hospital, radio-iron red cell volume, dye plasma volume and total blood volume were measured before and after a large

New York City, in collaboration with Drs. Andre Cournand and Alice Lowell. The preparation for and radioactivity analyses of samples were carried out in our laboratories. We wish to express our gratitude for permission to use these data.

\section{EXPERIMENT NO. CR-1 1-22-45}

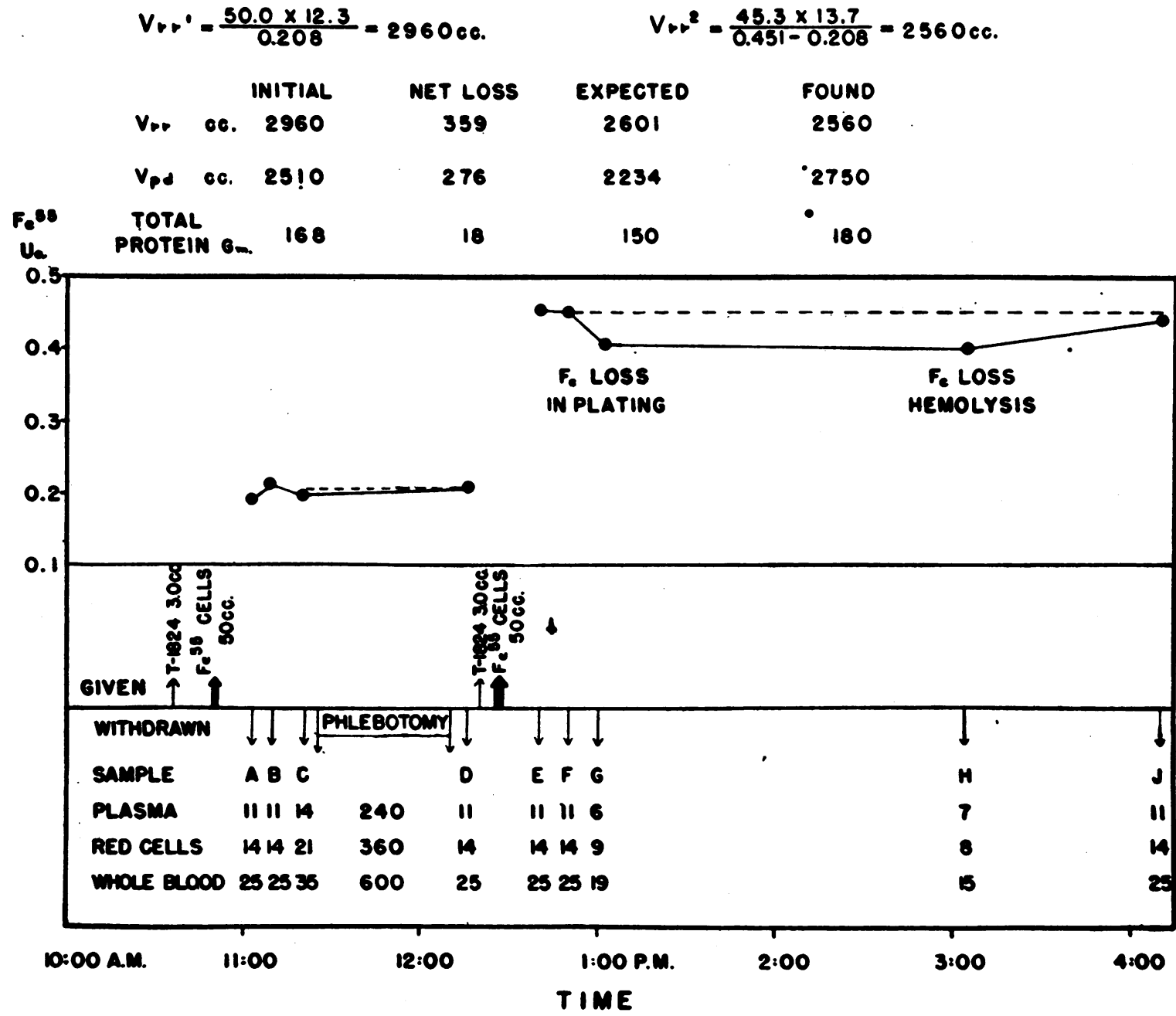

Fig. 4. Determination of Circulating Red Cell Volume Before and After Phlebotomy by Means of RADIOACTIVE IRON

Fifty ml. of cells tagged with $\mathrm{Fe}^{\mathrm{ss}}$ were injected for determination of the initial cell volume $\left(\mathrm{Vrr}_{1}\right)$. The $\mathrm{Ua}$ of these cells was 12.3, and the Ua of the recipient's cells after mixing averaged $0.208, \mathrm{making}^{\mathrm{Vrr}} \mathrm{rr}_{1}=2960 \mathrm{ml}$. The net loss in cells from phlebotomy, and cells withdrawn in samples A-D inclusive was 359, so that the expected post-phlebotomy cell volume was $2601 \mathrm{ml}$. The recipient's cell Ua was not altered by the phlebotomy, indicating complete mixing of the tagged with the recipient's cells. $45.3 \mathrm{ml}$. of cells tagged with $\mathrm{Fe}^{\mathrm{ss}}$ were injected for the post-phlebotomy cell volume $\left(\mathrm{Vrr}_{2}\right)$ determination. As a result, the recipient's cell Ua rose to an average value of 0.451 (values of samples $G$ and $H$ in which loss of iron in processing was known to have occurred were discarded), or $\mathrm{Vrr}_{2}=2560 \mathrm{ml}$., i.e., $41 \mathrm{ml}$. of cells less than the expected cell volume, an error of +1.6 per cent. 
phlebotomy, follows. The significant data are shown in Figure 4.

Experiment No. CR-1. January 20, 1945.

Subject: F. D. Age 62. Height, $63.5 \mathrm{~cm}$. Weight, $70.5 \mathrm{kgm}$.

Diagnosis: Emphysema with secondary polycythemia.

The patient lay in bed in a semi-reclining position throughout the experiment. All blood samples were taken through an indwelling cannula in the femoral artery. Dye and radioactive cells were given into a median cephalic vein. Patient was bled from the femoral artery.

Radioactive cells were obtained from a previously prepared patient with polycythemia and were group-O. Since the donor's serum anti-A titre was not known, his blood was taken in 4 per cent sodium citrate, centrifuged, the plasma removed and the cells resuspended in a volume of isotonic citrate-saline solution equal to the removed plasma. Patient experienced no untoward subjective symptoms.

Red cell volumes were calculated from the formula

$$
\text { - } \quad \text { Vrr }=\frac{\mathrm{CD} \times \mathrm{UaD}}{\mathrm{UaR}}
$$

where $\operatorname{Vrr}$ is the red cell volume by radio-iron, CD is the number of $\mathrm{ml}$. of donor cells given, $\mathrm{UaD}$ the radioactivity of the donor's cells, and $\mathrm{UaR}$ the radioactivity of the recipient's cells. Then

$$
\mathrm{Vrr}^{1}=\frac{50.2 \times 12.3}{.208}=2960 \mathrm{ml} \text {. }
$$

and

$$
\mathrm{Vrr}^{2}=\frac{45.3 \times 13.7}{.451-.208}=2560 \mathrm{ml}
$$

The average $\mathrm{Ua}$ of the recipient's samples taken after each infusion of cells has been used. Values known to be low due to observed loss of iron in plating and to hemolysis were discarded, as was the venous sample $\mathrm{CR}$ lj. $\mathrm{Vrr}^{2}$ was calculated from the net $\mathrm{Ua}$ level due to the second infusion of cells.

The dye plasma and radio-iron cell volume, measured before and after phlebotomy, are given in Table IV. For purposes of comparison, the red cell volume calculated from the dye-plasma-hematocrit is also given.

This protocol illustrates several points. The value for $\mathrm{Vrr}^{1}$ includes the patient's total red cell volume, and also the radioactive cells given for determination of that volume. $\mathrm{Vrr}^{2}$ includes the patient's residual cells after bleeding, plus the second infusion of radioactive cells minus cells removed in sampling after the first infusion.

The quantity of cells withdrawn by phlebotomy was measured by the radio-iron technique with an error of -2.2 per cent. At both volume measurements $\mathrm{Vrr}$ was less than Vrpd, by 22 and 26 per cent respectively. The calculated dye-plasma-hematocrit red cell volumes did however measure known red cell loss with considerable accuracy. The patient added 12 grams of protein to his circulation after hemorrhage and there was an increase of $510 \mathrm{ml}$. of plasma over the expected values. The arterial hematocrit was lowered by this hemodilution, but not to as great an extent as was the average body hematocrit.

\begin{tabular}{|c|c|c|c|c|c|c|c|}
\hline \multirow{2}{*}{ Time } & \multirow{2}{*}{ Procedure } & \multirow{2}{*}{ Sample no. } & \multicolumn{4}{|c|}{ Blood withdrawn } & \multirow{2}{*}{ Radioactivity } \\
\hline & & & $\begin{array}{l}\text { Whole } \\
\text { blood }\end{array}$ & Het. & Plasma & Cells & \\
\hline $\begin{array}{l}\text { 10:36 A.M. } \\
10: 48 \\
10: 51 \\
11: 02 \\
11: 09 \\
11: 21 \\
11: 25 \\
12: 05 \text { P.M. }\end{array}$ & \multirow{3}{*}{$\begin{array}{l}3.0 \mathrm{ml} \text {. of } 0.5 \text { per cent T.1824 i.v. } \\
\text { Syringe } 4695-Y \\
100 \text { ml. of suspended } \\
\text { radioactive cells i.v. } \\
\text { Sample for dye plasma } \\
\text { Sample }\} \text { volume and } \\
\text { Sample } \\
600 \text { ml. of whole blood } \\
\text { withdrawn from femoral artery } \\
\text { at av. Hct. of } 60 \text { per cent } \\
\text { Samples } \\
3.0 \text { ml. of } 0.5 \text { per cent T.1824 i.v. } \\
100 \text { ml. of suspended } \\
\text { radioactive cells i.v. } \\
\text { Syringe } 4891-Y \\
\text { Sample } \\
\text { Sample } \\
\text { Sample for dye plasma } \\
\text { Sample } \\
\text { Sample }\} \text { radioactivity }\end{array}$} & $\begin{array}{l}\text { CD 1a } \\
\text { CD 1b } \\
\text { CR 1a } \\
\text { CR 1b' } \\
\text { CR 1c }\end{array}$ & $\begin{array}{l}25 \\
25 \\
35\end{array}$ & $\begin{array}{c}\text { per cent } \\
\\
50.2 \\
49.7 \\
60.3 \\
59.3 \\
59.8\end{array}$ & $\begin{array}{l}11 \\
11 \\
14\end{array}$ & $\begin{array}{l}50 \\
14 \\
14 \\
21\end{array}$ & $\begin{array}{c}U a \\
\\
12.5 \\
12.1 \\
0.191 \\
0.212 \\
0.197\end{array}$ \\
\hline $\begin{array}{l}12: 16 \\
12: 19 \\
12: 25 \\
12: 28\end{array}$ & & $\begin{array}{l}\text { CR 1d } \\
\text { CD 1b } \\
\text { CD 1c }\end{array}$ & 25 & $\begin{array}{l}57.7 \\
\\
45.3 \\
45.2\end{array}$ & 11 & 14 & $\begin{array}{l}0.206 \\
13.5 \\
13.9\end{array}$ \\
\hline $\begin{array}{r}12: 40 \\
12: 50 \\
1: 00 \\
3: 03 \\
4: 12\end{array}$ & & $\begin{array}{ll}C R & \text { le } \\
C R & \text { if } \\
C R & 1 \mathrm{~g} \\
C R & 1 . h \\
C R & 1 \mathrm{j}\end{array}$ & $\begin{array}{l}25 \\
25 \\
15 \\
15 \\
25\end{array}$ & $\begin{array}{l}56.6 \\
55.7 \\
57.7 \\
54.3 \\
57.2\end{array}$ & $\begin{array}{r}11 \\
11 \\
6 \\
7 \\
11\end{array}$ & $\begin{array}{r}14 \\
14 \\
9 \\
8 \\
14\end{array}$ & $\begin{array}{l}0.452 \\
0.450 \\
0.405^{*} \\
0.400^{* *} \\
0.438\end{array}$ \\
\hline
\end{tabular}

Experiment No. CR-1

January 20, 1945

* Sample hemolyzed. 
TABLE IV

Measurement of plasma (dye) and red cell volume (radio-iron) in a patient with secondary polycythemia before and after a large phlebotomy*

\begin{tabular}{|c|c|c|c|c|c|c|c|c|}
\hline & \multirow{2}{*}{$\begin{array}{c}\begin{array}{c}\text { Plasma } \\
\text { volume }\end{array} \\
\text { Vpd }\end{array}$} & \multicolumn{2}{|c|}{$\begin{array}{l}\text { Directly measured } \\
\text { by radio-iron }\end{array}$} & \multicolumn{2}{|c|}{$\begin{array}{l}\text { Calculated from dye- } \\
\text { plasma-hematocrit }\end{array}$} & \multirow{2}{*}{$\frac{\begin{array}{c}\text { Arterial } \\
\text { hematocrit }\end{array}}{\text { Hav }}$} & \multirow{2}{*}{$\begin{array}{c}\begin{array}{c}\text { Average } \\
\text { body } \\
\text { hematocrit }\end{array} \\
\mathrm{Hb}\end{array}$} & \multirow[t]{2}{*}{$R=\frac{V r r}{V r p d}$} \\
\hline & & Vrr & Vwr & Vrpd & Vwpd & & & \\
\hline Before phlebotomy & $\begin{array}{c}m l . \\
2510\end{array}$ & $\begin{array}{c}m l . \\
2960\end{array}$ & $\begin{array}{c}m l . \\
5470\end{array}$ & $\begin{array}{c}m l . \\
3740\end{array}$ & $\begin{array}{c}m l . \\
6250\end{array}$ & $\begin{array}{c}\text { per cent } \\
59.8\end{array}$ & $\begin{array}{c}\text { per cent } \\
53.8\end{array}$ & 0.79 \\
\hline $\begin{array}{l}{ }^{* *} \text { Plasma and red cell loss } \\
\text { (direct measurement) }\end{array}$ & 286 & 359 & 645 & 313 & 599 & & & \\
\hline †Calculated volumes after bleeding & 2224 & 2601 & 4825 & 3427 & 5651 & & & \\
\hline Measured volume after bleeding & 2750 & 2560 & 5310 & 3510 & 6260 & 56.1 & 48.3 & 0.73 \\
\hline
\end{tabular}

Symbols: Vpd = Dye plasma volume; Vrpd and Vwpd = red cell and total blood volume calculated from plasma volume and hematocrit.

Vrr $=$ Red cell volume measured by radio-iron.

$\mathrm{Vwr}=$ Total blood volume $=\mathrm{Vpd}+\mathrm{Vrr}$.

Hav = Large vessel hematocrit (in this case arterial).

$\mathrm{Hb}=\frac{\mathrm{Vrr}}{\mathrm{Vwr}}$ or average body hematocrit.

* Experiment No. CR-1, Bellevue Hospital, January 23, 1945.

** Includes blood taken from samples.

† Corrected for second transfusion of radioactive cells.

\section{COMMENT}

The specificity and objectivity of the method described make it a desirable research tool in clinical investigation.

We have applied the method, with suitable modifications, to the study of a wide variety of experimental conditions. The normal red cell volume in humans and dogs has been studied. We have investigated shock experimentally produced by hemorrhage, muscle crushing, arterial occlusion, burns and bacillary toxins. The results have thrown light on many aspects of circulatory collapse. In the course of following changes in total cell volume in shock, it became evident that the withdrawal of red cells from active circulation was characteristic of severe collapse. The technique has been applied in a manner designed to directly measure the quantities of both plasma and cells normally coursing through the minute vessels, and the extent to which cells are trapped in the capillaries of the several vital organs in deep shock.

The method has also been adapted to the measurement of post-transfusion survival of human erythrocytes stored, both as whole blood and packed cells, in a number of preservative solutions. Findings are now in preparation for reporting.
These studies have been conducted in collaboration with many investigators, and will be reported in later communications.

\section{SUM MARY}

1. A method of determining circulating red cell volume by means of either of two radioactive isotopes of iron, based on the original technique of Hahn and associates, is described.

2. The method gives an absolute measure of the circulating red cells, which is independent of the venous, arterial or auricular hematocrit.

3. Repeat red cell volume measurements can be determined without errors arising from residual red cell radioactivity levels.

4. When used in conjunction with the dye plasma volume methods, the method provides an accurate measurement of circulating total blood volume.

\section{BIBLIOGRAPHY}

1. Gibson, J. G., 2nd, and Evans, W. A., Jr., Clinical studies of the blood volume. I. Clinical application of a method employing the azo dye "Evans blue" and the spectrophotometer. J. Clin. Invest., 1937, 16, 301 .

2. Gibson, J. G., 2nd, and Evelyn, K. A., Clinical studies of the blood volume. IV. Adaptation of the method 
to the photoelectric microcolorimeter. J. Clin. Invest., 1938, 17, 153.

3. Evans, E. I., Hoover, M. J., James, G. W., III, and Alm, T., Studies on traumatic shock. I. Blood volume changes in traumatic shock. Ann. Surg., 1944, 119, 64.

4. Price, P. B., and Longmire, W. P., The use of T1824 in plasma volume determinations. Bull. Johns Hopkins Hosp., 1942, 71, 51.

5. Heyl, J. T., Gibson, J. G., 2nd, and Janeway, C. A., Studies on the plasma proteins. V. The effect of concentrated solutions of human and bovine serum albumin on blood volume after acute blood loss in man. J. Clin. Invest., 1943, 22, 763.

6. Scatchard, G., Batchelder, A. C., and Brown, A., Chemical, clinical and immunological products of human plasma fractionation. VI. The osmotic pressure of plasma and of serum albumin. J. Clin. Invest., 1944, 23, 458.

7. Smith, H. P., Arnold, H. R., and Whipple, G. H., Blood volume studies: VII. Comparative values of Welcker, carbon monoxide and dye methods for blood volume determinations; accurate estimation of absolute blood volume. Am. J. Physiol., 1921, 56, 336.

8. Keith, N. M., Rowntree, L. G., and Geraghty, J. T., A method for determination of plasma and blood volume. Arch. Int. Med., 1915, 16, 547.

9. Fåhraeus, R., The suspension stability of the blood. Physiol. Rev., 1929, 9, 241.

10. Ebert, R. V., Stead, E. A., Jr., and Gibson, J. G., 2nd, Response of normal subjects to acute blood loss, with special reference to the mechanism of restoration of blood volume. Arch. Int. Med., 1941, 68, 578.

11. Idem, Relationship of the plasma volume and the cell plasma ratio to the total red cell volume. Am. J. Physiol., 1941, 132, 411.

12. Chang, H. C., and Harrop, G. A., Jr., The determination of the circulating blood volume with carbon monoxide. J. Clin. Invest., 1928, 5, 393.

13. Hopper, J., Jr., Tabor, H., and Winkler, A. W., Simultaneous measurements of the blood volume in man and dog by means of Evans blue dye, T1824, and by means of carbon monoxide. I. Normal subjects. J. Clin. Invest., 1944, 23, 628.

14. Hopper, J., Jr., Winkler, A. W., and Elkinton, J. R., Simultaneous measurements of the blood volume in man and dog by means of Evans blue dye, T1824, and by means of carbon monoxide. II. Under $a b-$ normal conditions, including secondary shock. J. Clin. Invest., 1944, 23, 636.

15. Hahn, L., and Hevesy, G., A method of blood volume determination. Acta Med. Scandinav., 1940, $1,3$.

16. Hahn, P. F., Ross, J. F., Bale, W. F., and Balfour, W. M., Red cell and plasma volumes (circulating and total) as determined by radio iron and by dye. J. Exper. Med., 1942, 75, 221.

17. Peacock, W. C., Evans, R. D., Irvine, J. W., Jr., Good, W., Kip, A. F., Weiss, S., and Gibson, J. G., 2nd, The use of two radioactive isotopes of iron in tracer studies of erythrocytes. J. Clin. Invest., 1946, 25, 605. 